\title{
Pengembangan Usaha Budidaya Ikan Lele (Clarias sp.) di Lahan Kering di Kabupaten Gunungkidul, Provinsi Daerah Istimewa Yogyakarta
}

\author{
Business Development Farming Catfish (Clarias sp.) on Dry Land \\ In Gunung Kidul Regency, DI Yogjakarta Province \\ Denny Jatnika ${ }^{* 1}$, Komar Sumantadinata ${ }^{2}$, dan Nora H. Pandjaitan ${ }^{3}$ \\ ${ }^{1}$ Kementerian Kelautan dan Perikanan \\ Gd. Mina Bahari III lt. 13 Jl. Medan Merdeka Timur No. 16, Jakarta Pusat 10110 \\ ${ }^{2}$ Departemen Budidaya Perikanan, Fakultas Perikanan dan Ilmu Kelautan, Institut Pertanian Bogor \\ Jl. Agatis, Kampus IPB Darmaga, Bogor 16680 \\ ${ }^{3}$ Departemen Teknik Sipil dan Lingkungan, Fakultas Teknologi Pertanian, Institut Pertanian Bogor \\ Jl. Kamper, Kampus IPB Darmaga, Bogor 16680
}

\begin{abstract}
ABSTRAK
Salah satu komoditas perikanan yang sangat prospektif untuk dibudidayakan dalam skala industri dan rumah tangga adalah ikan lele (Clarias sp.). Tujuan kajian ini: (1) menganalisis kelayakan budidaya ikan lele di lahan kering di Kabupaten Gunung Kidul, Yogyakarta (2) menganalisa potensi budidaya ikan lele di kolam terpal di tanah kering, (3) mengembangkan usaha alternatif di Kabupaten Gunung Kidul Yogyakarta. Metode yang digunakan dalam penelitian ini adalah metode deskriptif yang berfokus pada aspek teknis dan budidaya pengembangan usaha, serta analisis Strengths, Weaknesses, Opportunities dan Threats (SWOT). Berdasarkan analisis kelayakan memiliki prospek yang menjanjikan dan layak untuk dikembangkan. Untuk memaksimalkan pendapatan petani lele, kombinasi strategi SO, strategi WO dan strategi ST merupakan strategi yang tepat untuk dipilih petani. Untuk memaksimalkan pendapatan pembudidaya ikan lele, dilakukan penambahan jumlah dan luas kolam, serta mengembangkan usaha budidaya, menerapkan cara-cara pemeliharaan dan budidaya yang baik, serta memperluas jangkauan pasar mulai dari konsumen perorangan, pasar tradisional rumah makan dan restoran hingga ke pasar modern untuk meningkatkan efisiensi modal dan meningkatkan keuntungan bagi petani lele pada lahan kering di Kabupaten Gunung Kidul
\end{abstract}

Kata kunci: pengembangan usaha, ikan lele, budidaya, lahan kering

\section{ABSTRACT}

The one commodity that is highly prospective for cultivated on an industrial scale and households are catfish (Clarias sp.). The purpose of this study was (1) analyze the feasibility of catfish farming in dry land in the district of Gunung Kidul Yogyakarta Province, (2) analyze the potential of catfish farming in ponds tarp on dry land, (3) develop alternative business development in the district of Gunung Kidul Yogyakarta Province. The method used in this thesis is descriptive method that focuses on technical aspects and business cultivation, as well as a SWOT analysis. Based on the feasibility analysis has a promising prospect and deserves to be developed. To maximize revenue catfish farmers, a combination of strategies SO, WO Strategies and strategy ST is an appropriate strategy to be chosen by farmers to improve their business. Increase the number and extent of ponds and develop farming, applying methods of maintenance and cultivation of good, as well as expand market coverage ranging from individual consumers, restaurants and traditional markets to restaurants to modern markets to improve capital efficiency and increase profits for farmers catfish on dry land in the district of Gunung Kidul.

Key words: business development, catfish, cultivation, dry land

\footnotetext{
*) Korespondensi:

Gd. Mina Bahari III lt. 13 Jl. Medan Merdeka Timur No.16, Jakarta Pusat 10110; e-mail: deje2010@gmail.com
} 


\section{PENDAHULUAN}

Indonesia merupakan negara dengan tingkat pertumbuhan penduduk semakin tinggi dari tahun ke tahun. Hal ini menyebabkan tingkat kebutuhan konsumsi protein yang berasal dari ikan semakin meningkat. Salah satu komoditas perikanan yang sangat prospektif untuk dibudidayakan dalam skala industri maupun rumah tangga adalah ikan lele (Clarias sp.). Di Indonesia ikan lele mempunyai beberapa nama daerah, antara lain ikan kalang (Padang), ikan maut (Gayo, Aceh), ikan pintet (Kalimantan Selatan), ikan keling (Makasar), ikan cepi (Bugis), ikan lele atau lindi (Jawa Tengah) (Kantor Deputi Menegristek Bidang Pendayagunaan dan Pemasyarakatan Ilmu Pengetahuan dan Teknologi, 2000). Empat variasi warna ikan lele yang diperjualbelikan, yakni hitam, putih, merah dan belang. Ikan lele konsumsi biasanya berwarna hitam kelabu, sedangkan yang berwarna putih, merah dan belang umumnya diperjualbelikan sebagai ikan hias (Gunawan 2009).

Produksi ikan lele ukuran konsumsi secara nasional mengalami kenaikan 18,3\%/tahun yaitu dari 24.991 ton pada tahun 1999 menjadi 57.740 ton pada tahun 2003. Revitalisasi ikan lele sampai dengan akhir tahun 2009 ditargetkan mencapai produksi 175.000 ton atau meningkat rataan 21,64\%/tahun. Kebutuhan benih ikan lele mengalami peningkatan pesat yaitu dari 156 juta ekor pada tahun 1999 menjadi 360 juta ekor pada tahun 2003 atau meningkat rataan 46\%/tahun. Kebutuhan benih lele diperkirakan mencapai 1,95 miliar ekor pada akhir 2009 (Mahyuddin 2010).

Secara umum terdapat dua alasan perlunya peningkatan konsumsi ikan masyarakat, yaitu pertama adalah untuk meningkatkan mutu sumber daya manusia (SDM) Indonesia dengan meningkatnya asupan masyarakat akan protein dan gizi yang berasal dari ikan, serta kedua adalah peningkatan konsumsi ikan, akan mendorong pengembangan industri ikan lele di Indonesia, khususnya dalam aspek pemasaran dan pengolahan. Dahulu ikan lele dipandang ikan murahan dan hanya dikonsumsi oleh keluarga petani, sekarang ikan lele merupakan komoditas yang sangat disukai oleh masyarakat (Sukardono el al, 2013). Selain itu rasa daging yang khas, serta cara memasak dan menghidangkan secara tradisional, menjadikan menu sajian ikan lele digemari masyarakat luas (Jaja et al, 2013).

Alih guna lahan-lahan produktif menjadi daerah pemukiman membuat lahan yang dapat dimanfaatkan, terutama untuk usaha budidaya di bidang perikanan menjadi terbatas. Salah satu solusi untuk mengatasinya dengan pemanfaatan lahan non-produktif atau lahan-lahan marginal sebagai media budidaya di bidang perikanan, seperti budidaya lele dengan kolam terpal. Ketahanan lele di air yang tidak mengalir membuat budidaya lele mudah diterapkan meskipun pada lahan sempit dan kering. Usaha budidaya lele tidak membutuhkan biaya besar, mudah dan waktu pemeliharaannya singkat, sehingga cepat memberikan hasil bagi pembudidayanya. Berbeda dengan jenis ikan lain yang sangat rentan terhadap penyakit, lele tidak membutuhkan perhatian khusus saat pemeliharaan.

Berdasarkan latar belakang, tujuan dari kajian ini adalah (1) menganalisis kelayakan usaha budidaya ikan lele di lahan kering dengan menggunakan kolam terpal di Kabupaten Gunungkidul Provinsi Daerah Istimewa Yogyakarta (DIY), (2) menganalisis potensi budidaya ikan lele di lahan kering dengan menggunakan kolam terpal, dan (3) menyusun alternatif pengembangan usaha budidaya ikan lele dengan menggunakan kolam terpal di lahan kering di Kabupaten Gunungkidul Provinsi DIY.

\section{METODOLOGI}

Kajian ini dilakukan di Kabupaten Gunungkidul Provinsi Daerah Istimewa Yogyakarta terhadap pembudidaya yang sedang mengembangkan budidaya ikan lele dengan menggunakan kolam terpal. Waktu kajian dilaksanakan pada bulan April sampai Juni 2011.

Data yang dibutuhkan berupa data primer dari sejumlah 44 pembudidaya ikan lele di lahan kering dengan menggunakan kolam terpal yang diambil sebagai contoh di Kecamatan Playen, Kabupaten Gunungkidul, mewakili sebanyak 422 pembudidaya ikan lele, serta data sekunder yang diperoleh dari hasil studi pustaka (buku, jurnal dan penelitian terdahulu), serta laporan dari instansi terkait, seperti Kementerian Kelautan dan Perikanan, Dinas Kelautan dan Perikanan Provinsi dan Kabupaten, Badan Pusat Statistik dan Pemerintah Daerah, terkait dengan teknis budidaya ikan lele di lahan kering, potensi pasar ikan lele, potensi pemasaran, serta usaha diversifikasi produk ikan lele menjadi olahan.

Kajian analisis ekonomi yang terdiri dari aspek pemasaran dan aspek pembiayaan, dilakukan untuk mengetahui kelayakan usaha dari 
usaha budidaya ikan lele di lahan kering. Aspek pemasaran meliputi kondisi permintaan produk ikan lele untuk memenuhi kebutuhan pasar, penawaran yang memberikan gambaran tentang ketersediaan produk dalam proses usaha budidaya serta faktor keseimbangan antara permintaan dan penawaran harga, yang memberikan gambaran tentang mekanisme penetapan harga jual produk, hubungan antara harga jual dengan permintaan, serta faktor-faktor yang mempengaruhi harga jual produk, persaingan dan peluang pasar serta pemasaran produk ikan lele. Kelayakan finansial usaha budidaya ikan lele di lahan kering dinilai dengan menggunakan teknik berikut Net Present Value (NPV), Benefit Cost Ratio (BCR), Internal Rate of Return (IRR), Analisis Break Even Point (BEP) dan Payback Period (PBP).

Untuk mengkaji strategi pengembangan usaha budidaya ikan lele di lahan kering di Kabupaten Gunungkidul dilakukan dengan analisis SWOT kuantitatif. Dua pendekatan dalam analisis SWOT, yaitu:

1. Pendekatan Kualitatif Matriks SWOT

Pendekatan kualitatif matriks SWOT menampilkan delapan kotak, yaitu dua paling atas adalah kotak faktor eksternal (Peluang dan Tantangan) usaha, sedangkan dua kotak sebelah kiri adalah faktor internal (Kekuatan dan Kelemahan). Empat kotak lainnya merupakan kotak isu-isu strategik yang timbul sebagai hasil titik pertemuan antara faktor-faktor internal dan eksternal usaha budidaya tersebut.

2. Pendekatan Kuantitatif Analisis SWOT

Data SWOT kualitatif di atas dapat dikembangkan secara kuantitatif melalui perhitungan Analisis SWOT yang dikembangkan Pearce dan Robinson (1998) agar diketahui secara pasti posisi organisasi sesungguhnya.

Analisis lingkungan usaha budidaya ikan lele pada lahan kering dengan analisis deskriptif dilakukan terhadap faktor internal dan eksternal. Lingkungan internal terdiri atas lima faktor, yaitu:

1. Misi dan tujuan dari pengembangan usaha budidaya ikan lele pada lahan kering;

2. Fasilitas dan kegiatan produksi, meliputi data sarana dan prasarana produksi, proses produksi dan penanganan pascaproduksi;

3. SDM yang meliputi data mengenai jumlah pembudidaya yang bekerja pada usaha budidaya ikan lele dan fasilitas bagi pembudidaya, jumlah tenaga kerja, serta tingkat pendidikan dan keterampilan pada usaha budidaya ikan lele pada lahan kering.

4. Sumber daya keuangan, meliputi aspek permodalan usaha budidya ikan lele pada lahan kering;

5. Sumber daya pasar dan pemasaran, yang meliputi data mengenai pemasaran produk ikan lele (mulai dari bibit, hingga lele siap panen).

Lima faktor lingkungan eksternal, adalah:

1. Sosial ekonomi yang terdiri dari data kondisi, demografi dan sosial.

2. Tingkat kemajuan teknologi.

3. Sistem pembelian serta harga bibit dan sarana produksi perikanan lainnya.

4. Pesaing meliputi ancaman pendatang baru, daya tawar pembeli dan persaingan dalam usaha dalam komoditi ikan lele.

5. Peran dari pemerintah, meliputi kebijakan pemerintah dan dukungan sarana serta prasarana bagi pengembangan usaha budidaya ikan lele.

\section{HASIL DAN PEMBAHASAN}

Kabupaten Gunungkidul adalah salah satu kabupaten yang ada di Propinsi DIY, dengan ibukotanya Wonosari. Luas wilayah Kabupaten Gunungkidul 1.485,36 $\mathrm{km}^{2}$ atau sekitar 46,63\% dari luas wilayah Propinsi DIY. Kota Wonosari terletak di sebelah tenggara kota Yogjakarta (Ibukota Propinsi DIY), dengan jarak kurang lebih 39 km. Wilayah Kabupaten Gunungkidul dibagi menjadi 18 Kecamatan dan 144 desa. Letak geografi: $110^{\circ} 21^{\prime}$ sampai $110^{\circ} 50^{\prime}$ Bujur Timur 70 46'sampai 80 09' Lintang Selatan (BPS, 2008).

Jenis ikan lele yang banyak dibudidayakan adalah lele Sangkuriang, Phyton dan lele dumbo. Benih ikan lele tersebut diperoleh pembudidaya dari usaha pembenihan rakyat (UPR) di sekitar Kabupaten Gunungkidul dan sebagian kecil diperoleh dari UPR Kabupaten Sleman dan Kabupaten Bantul. Produksi rataan ikan lele di Kecamatan Playen Kabupaten Gunungkidul pada tahun 2010 menurut Dinas Kelautan dan Perikanan Kabupaten Gunungkidul adalah 573.645 $\mathrm{Kg}$, dengan jumlah rataan produksi benih ikan lele 6.676.973 ekor. Jumlah panen rataan yang dilakukan oleh pembudidaya adalah 3 kali dalam setahun, dengan rataan umur pemeliharaan selama 2,5-3 bulan. 


\section{Analisis Kelayakan Usaha}

Perhitungan finansial mengenai pendapatan dan biaya usaha, kemampuan usaha untuk membayar kredit dan kelayakan usaha memerlukan dasar-dasar perhitungan yang diasumsikan berdasarkan hasil survei dan pengamatan yang terjadi di lapangan serta informasi dari beberapa literatur. Asumsi yang digunakan dalam perhitungan aspek keuangan ini disajikan pada Tabel 1 dari seluruh pembudidaya ikan lele di Kecamatan Playen Kabupaten Gunungkidul. Kolam terpal yang dimiliki oleh pembudidaya ikan lele di Kecamatan Playen Kabupaten Gunungkidul dapat dikelompokkan menjadi tiga kelompok besar, yaitu ukuran antara 12-16 m², 20-25 $\mathrm{m}^{2}$ dan $30-45 \mathrm{~m}^{2}$. Selain itu tenaga kerja juga diperhatikan, yaitu yang memiliki kemampuan dan keahlian dalam mengembangkan kolam terpal tersebut. Menurut Septiara et al (2012), tingkat pendidikan merupakan salah satu faktor yang memengaruhi kemampuan berpikir dan kemampuan menyerap informasi dan inovasi.

Tabel 1. Asumsi teknis dalam analisis usaha budidaya ikan Lele

\begin{tabular}{c|l}
\hline No. & \multicolumn{1}{|c}{ Uraian } \\
\hline 1. & $\begin{array}{l}\text { Pemeliharaan menggunakan kolam terpal } \\
\text { Usaha budidaya ikan lele dilakukan pada } \\
\text { lahan kering. }\end{array}$ \\
3. & $\begin{array}{l}\text { Usaha budidaya yang dilakukan adalah } \\
\text { pembesaran ikan lele konsumsi. } \\
\text { Tingkat suku bunga kredit Bank Mandiri } \\
\text { periode Januari-Juli 2011 sebesar 15\%. } \\
5 .\end{array}$ \\
\hline
\end{tabular}

\section{Kelayakan Usaha pada Kolam 12-16 m²}

1. Biaya Investasi

Biaya investasi bervariasi, tergantung kepada luas atau ukuran kolam terpal yang dimiliki oleh pembudidaya dan peralatan yang digunakan selama proses produksi Rp259.515.

2. Biaya Operasional

Total pengeluaran selama periode budidaya adalah Rp3.840.952,36 dengan perincian biaya investasi Rp259.515 biaya tetap Rp311.250 dan biaya variabel Rp3.417.451,52 sehingga diperoleh keuntungan bersih Rp832. 668,59 atau rataan senilai Rp277.556,20/siklus budidaya.

3. Produksi dan Pendapatan

Berdasarkan analisa keuangan, harga jual ikan lele konsumsi selama periode budidaya, yaitu harga rataan Rp10.394,74/kilogram ditingkat pembudidaya. Usaha budidaya ikan lele di lahan kering dengan menggunakan kolam terpal di Kabupaten Gunungkidul pada luas kolam 12-16 $\mathrm{m}^{2}$ sudah dapat menghasilkan pada tahun pertama sejak panen pertama yaitu, pada bulan ketiga budidaya. Pendapatan Rp4.673.620,95 diperoleh dari hasil penjualan dari 3.643 ekor ikan lele setara $453,88 \mathrm{~kg}$ ikan lele konsumsi dan rataan tingkat keberhasilan usaha budidaya lele di lahan kering $76,58 \%$.

Berdasarkan laporan keuangan usaha budidaya ikan lele di lahan kering di Kecamatan Playen Kabupaten Gunungkidul memberikan keuntungan pada tahun pertama budidaya Rp832.668,59 pada periode budidaya selama satu tahun atau Rp277.556,20/siklus budidaya atau selama tiga bulan pemeliharaan.

Dari perhitungan Analisis Kelayakan Usaha ditingkat pembudidaya, usaha budidaya ikan lele di lahan kering dengan menggunakan kolam terpal di Kabupaten Gunungkidul dengan luas kolam 12-16 $\mathrm{m}^{2}$, diperoleh BEP pada volume produksi adalah $344,54 \mathrm{~kg}$, atau harga diperoleh Rp7.890,78/kg, yang berarti usaha budidaya ikan lele di lahan kering akan mencapai titik impas jika volume produksi selama satu periode budidaya dapat mencapai $344,54 \mathrm{~kg}$, atau harga jual mencapai Rp7.890,78/kg (Tabel 2).

Bila dilihat dari Gross B/C Ratio, suatu proyek dikatakan menguntungkan jika nilai Gross $B / C$ Ratio lebih dari 1. Dari hasil analisa diperoleh nilai Gross B/C Ratio 1,22, yaitu proyek layak untuk dijalankan atau setiap modal Rp100 yang dikeluarkan akan memperoleh pendapatan Rp122 atau diperoleh keuntungan Rp22.

Berdasarkan kriteria jangka waktu pengembalian modal (PBP) diperoleh hasil 3,81 tahun, dimana diperlukan 10 kali siklus panen (3 periode) budidaya ikan lele di lahan kering agar semua biaya investasi yang telah dikeluarkan dapat kembali. Dari hasil analisa keuangan, terlihat usaha budidaya ikan lele di lahan kering dengan menerapkan pola pemeliharaan dengan menggunakan kolam terpal di Kabupaten Gunungkidul dengan luas kolam 12-16 $\mathrm{m}^{2}$ layak untuk diusahakan, karena dapat memberikan keuntungan. 
Tabel 2. Perhitungan analisis keuangan usaha budidaya ikan Lele di lahan kering di Kabupaten Gunungkidul (Luas Kolam 12-16 m²)

\begin{tabular}{|c|c|c|}
\hline No. & Uraian & Total \\
\hline 1. & $\mathrm{~B} / \mathrm{C}$ Ratio $=$ penerimaan total $/$ biaya total & 1,22 \\
\hline 2. & Cash Flow $=$ keuntungan + biaya penyusutan & Rp909.891 \\
\hline 3. & $\mathrm{PBP}=($ biaya investasi + biaya variabel $) /$ cash flow & 3,81 (Tahun) \\
\hline 4. & Biaya perkg = total biaya produksi/total panen & $\mathrm{Rp} 7.890,78 / \mathrm{Kg}$ \\
\hline \multirow[t]{3}{*}{5.} & $\mathrm{BEP}=$ biaya tetap/ (1-(biaya variabel/ pendapatan) & Rp3.581.437,12/Kg \\
\hline & $\mathrm{BEP}$ volume = total biaya produksi $/$ harga jual $/ \mathrm{kg}$ & $344,54 \mathrm{Kg}$ \\
\hline & $\mathrm{BEP}$ harga = total biaya produksi/total produksi & $\mathrm{Rp} 7.890,78 / \mathrm{Kg}$ \\
\hline 6. & Tingkat Suku Bunga Kredit Bank (r) (Januari - Juli 2011) & $15,00 \%$ \\
\hline 7. & IRR $=$ PV Pengeluaran/Cash Flow -1 & $3,22 \%$ \\
\hline \multirow[t]{3}{*}{8.} & $\mathrm{NPV}=\mathrm{PV}$ penerimaan $-\mathrm{PV}$ pengeluaran & Rp724.059,65 \\
\hline & PV Penerimaan $=$ penerimaan $/(1+r)$ & Rp4.064.018,22 \\
\hline & PV Pengeluaran $=($ Total biaya pengeluaran $) /(1+r) 0$ & Rp3.339.958,57 \\
\hline
\end{tabular}

\section{Kelayakan Usaha pada Kolam 20-25 m $^{2}$}

\section{Biaya Investasi}

Biaya investasi pada usaha budidaya ikan lele dengan luas kolam 20-25 m² yang digunakan selama proses produksi Rp850.739,64.

2. Biaya Operasional

Total pengeluaran selama periode budidaya Rp6.946.433,77 dengan perincian biaya investasi Rp850.739,64, biaya tetap Rp84.615,38 dan biaya variabel Rp6.011.078,74 sehingga diperoleh keuntungan bersih Rp2.248.907,48 atau rataan senilai Rp749.635,83/siklus budidaya.

3. Produksi dan Pendapatan

Berdasarkan analisa keuangan, harga jual ikan lele konsumsi selama periode budidaya dengan harga rataan Rp10.673,08/kg ditingkat pembudidaya. Usaha budidaya ikan lele di lahan kering dengan menggunakan kolam terpal di Kabupaten Gunungkidul pada luas kolam 20-25 $\mathrm{m}^{2}$ sudah dapat menghasilkan pada tahun pertama sejak panen pertama yaitu pada bulan ketiga budidaya. Pendapatan Rp9.195.341 diperoleh dari hasil penjualan dari 7.180 ekor ikan lele setara $868 \mathrm{~kg}$ ikan lele konsumsi, rataan tingkat keberhasilan usaha budidaya lele di lahan kering $81,15 \%$.

Berdasarkan laporan keuangan usaha budidaya ikan lele di lahan kering di Kecamatan Playen Kabupaten Gunungkidul memberikan keuntungan pada tahun pertama budidaya Rp2.248.907,48 pada periode budidaya selama satu tahun atau Rp749.635,83 per siklus budidaya atau selama tiga bulan pemeliharaan. Dari perhitungan analisis kelayakan usaha ditingkat pembudidaya, usaha budidaya ikan lele di lahan kering dengan menggunakan kolam terpal di Kabupaten Gunungkidul dengan luas kolam 20-
$25 \mathrm{~m}^{2}$, diperoleh BEP pada volume produksi $571,13 \mathrm{~kg}$, atau harga diperoleh $\mathrm{Rp} 7.020,22 / \mathrm{kg}$, yang berarti bahwa usaha budidaya ikan lele di lahan kering akan mencapai titik impas jika volume produksi selama satu periode budidaya dapat mencapai $571,13 \mathrm{~kg}$, atau harga jual mencapai Rp7.020,22/kg (Tabel 3).

Dari hasil analisa diperoleh nilai Gross B/C Ratio 1,32 menunjukkan proyek ini layak dijalankan, yang berarti bahwa setiap modal Rp100 yang dikeluarkan akan memperoleh pendapatan Rp132 atau diperoleh keuntungan Rp32.

Berdasarkan kriteria jangka waktu pengembalian modal (PBP) diperoleh hasil 2,97 tahun, dimana diperlukan 7 kali siklus panen dalam 3 periode budidaya ikan lele di lahan kering, agar semua biaya investasi yang telah dikeluarkan dapat kembali. Dari hasil analisa keuangan, terlihat bahwa usaha budidaya ikan lele di lahan kering dengan pola pemeliharaan kolam terpal di Kabupaten Gunungkidul pada luas kolam 20-25 $\mathrm{m}^{2}$ layak untuk diusahakan karena, dapat memberikan keuntungan.

\section{Kelayakan Usaha pada Kolam 30 - 45 m² $^{2}$}

1. Biaya Investasi

Biaya investasi usaha budidaya ikan lele dengan luas kolam 30-45 $\mathrm{m}^{2}$ yang digunakan selama proses produksi Rp1.245.405,78.

2. Biaya Operasional

Total pengeluaran selama periode budidaya Rp.9.561.009,94 dengan perincian biaya investasi Rp1.245.405,78, biaya tetap Rp.311.250,00 dan biaya variabel Rp8.004.354,17 sehingga diperoleh keuntungan bersih Rp3.245.323,85 atau rataan senilai Rp1.081.774,62/siklus budidaya. 
Tabel 3. Perhitungan analisis keuangan usaha budidaya ikan Lele di lahan kering di Kabupaten Gunungkidul (Luas Kolam 20-25 m²)

\begin{tabular}{c|l|l}
\hline No. & \multicolumn{1}{|c}{ Uraian } & \multicolumn{1}{|c}{ Total } \\
\hline 1. & B/C Ratio = penerimaan total/biaya total & 1,22 \\
2. & Cash Flow = keuntungan + biaya penyusutan & Rp2.310.446 \\
3. & PBP = (biaya investasi + biaya variabel)/cash flow & 2,97 (Tahun) \\
4. & Biaya per kg = total biaya produksi/total panen & Rp7.020,22/Kg \\
5. & BEP = biaya tetap/ (1-(biaya variabel/pendapatan) & $\mathrm{Rp} 17.602 .816,20 / \mathrm{Kg}$ \\
& BEP volume = total biaya produksi/harga jual/kg & $571,13 \mathrm{Kg}$ \\
& BEP harga = total biaya produksi/total produksi & $\mathrm{Rp} 7.020,22 / \mathrm{Kg}$ \\
7. & Tingkat Suku Bunga Kredit Bank (r) (Januari - Juli 2011) & $15,00 \%$ \\
8. & IRR = PV Pengeluaran/Cash Flow - 1 & $1,61 \%$ \\
& NPV = PV penerimaan - PV pengeluaran & $\mathrm{Rp} 1.955 .571,72$ \\
& PV Penerimaan = penerimaan/(1+r) & $\mathrm{Rp} 7.995 .948,91$ \\
\hline
\end{tabular}

3. Produksi dan Pendapatan

Berdasarkan analisa keuangan, harga jual ikan lele konsumsi selama periode budidaya dengan harga rataan Rp10.291,67/kg ditingkat pembudidaya. Usaha budidaya ikan lele di lahan kering dengan menggunakan kolam terpal di Kabupaten Gunungkidul pada luas kolam 30-45 $\mathrm{m}^{2}$ sudah dapat menghasilkan pada tahun pertama, sejak panen pertama, yaitu pada bulan ketiga budidaya. Pendapatan Rp.12.806.333,79 diperoleh dari hasil penjualan dari 10.661,01 ekor ikan lele setara $1.242,06 \mathrm{~kg}$ ikan lele konsumsi, rataan tingkat keberhasilan usaha budidaya lele di lahan kering $83,75 \%$.

Berdasarkan laporan keuangan usaha budidaya ikan lele di lahan kering di Kecamatan Playen Kabupaten Gunungkidul memberikan keuntungan pada tahun pertama budidaya Rp3.245.323,85 pada periode budidaya selama satu tahun atau Rp1.081.774,62/siklus budidaya atau selama tiga bulan pemeliharaan.

Dari perhitungan Analisis Kelayakan Usaha ditingkat pembudidaya, usaha budidaya ikan lele di lahan kering dengan kolam terpal di Kabupaten Gunungkidul luas kolam 30-45 m², diperoleh BEP pada volume produks $807,99 \mathrm{~kg}$, atau harga diperoleh $\mathrm{Rp} 6.695,01 / \mathrm{kg}$, yang berarti bahwa usaha budidaya ikan lele di lahan kering mencapai titik impas jika volume produksi selama satu periode budidaya dapat mencapai $807,99 \mathrm{~kg}$, atau harga jual mencapai Rp6.695,01/kg, seperti yang disajikan pada Tabel 4 .
Dari hasil analisa diperoleh nilai Gross B/C Ratio 1,34 menunjukan proyek ini layak untuk dijalankan, setiap modal Rp100 yang dikeluarkan akan memperoleh pendapatan Rp134 atau diperoleh keuntungan Rp34.

Berdasarkan kriteria jangka waktu pengembalian modal (PBP) diperoleh hasil 2,64 tahun, dimana diperlukan 7 kali siklus panen dalam 3 periode budidaya ikan lele di lahan kering agar semua biaya investasi yang telah dikeluarkan dapat kembali. Dengan melihat hasil analisa keuangan, menunjukan bahwa usaha budidaya ikan lele di lahan kering dengan menerapkan pola pemeliharaan dengan menggunakan kolam terpal di Kabupaten Gunungkidul dengan luas kolam 30-45 $\mathrm{m}^{2}$ layak untuk diusahakan karena dapat memberikan keuntungan.

\section{Strategi Pengembangan Usaha}

\section{Identifikasi Matriks Faktor Strategi Internal}

Hasil identifikasi matriks faktor strategi internal harus diuraikan untuk mengetahui kekuatan dan kelemahan yang dimiliki dalam usaha budidaya ikan lele di lahan kering di Kabupaten Gunungkidul untuk melakukan kegiatan operasionalnya sehari-hari. Dalam pengelolaan usaha budidaya ikan lele, pembudidaya harus mengupayakan langkah-langkah tepat untuk mengatasi kelemahan-kelemahan dalam usaha yang dilakukannya, agar dapat mengembangkan usahanya lebih baik. Faktor-faktor kekuatan dan kelemahan pada usaha budidaya ikan lele di lahan kering di Kabupaten Gunungkidul dapat dilihat pada Tabel 5. 
Tabel 4. Perhitungan analisis keuangan usaha budidaya ikan Lele di lahan kering di Kabupaten Gunungkidul (Luas Kolam 30-45 m²)

\begin{tabular}{cll}
\hline No. & \multicolumn{1}{c}{ Uraian } & \multicolumn{1}{c}{ Total } \\
\hline 1. & B/C Ratio = penerimaan total/biaya total & 1,34 \\
2. & Cash Flow = keuntungan + biaya penyusutan & Rp3.498.657 \\
3. & PBP = (biaya investasi + biaya variabel)/cash flow & 2,64 (Tahun) \\
4. & Biaya perkg = total biaya produksi/total panen & Rp6.695,01/Kg \\
5. & BEP = biaya tetap/ (1-(biaya variabel/ pendapatan) & Rp22.176.771,02/Kg \\
& BEP volume = total biaya produksi/harga jual/kg & $807,99 \mathrm{Kg}$ \\
& BEP harga = total biaya produksi/total produksi & $\mathrm{Rp} 6.695,01 / \mathrm{Kg}$ \\
6. & Tingkat Suku Bunga Kredit Bank (r) (Januari - Juli 2011) & $15,00 \%$ \\
7. & IRR = PV Pengeluaran/Cash Flow - 1 & $1,38 \%$ \\
8. & NPV = PV penerimaan - PV pengeluaran & $\mathrm{Rp} 2.822 .020,74$ \\
& PV Penerimaan = penerimaan/(1+r) & $\mathrm{Rp} 11.135 .942,43$ \\
& PV Pengeluaran = (Total biaya pengeluaran)/ (1+r)0 & $\mathrm{Rp} 8.313 .921,69$ \\
\hline
\end{tabular}

\section{Identifikasi Matriks Faktor Strategi Eksternal}

Faktor strategi eksternal yang meliputi faktor-faktor penting dalam usaha budidaya ikan lele di lahan kering dengan media kolam terpal yang dapat dijadikan sebagai peluang agar usaha yang sudah ada tetap pada jalur strategi yang benar. Peluang yang dapat dijadikan kekuatan berasal dari lingkungan mikro dan makro. Hasil identifikasi peluang dan ancaman yang dimasukkan sebagai faktor-faktor strategi eksternal dapat dilihat pada Tabel 6.

Berdasarkan identifikasi faktor strategik internal dan eksternal yang diperoleh, selanjutnya ditetapkan alternatif strategi dengan matriks internal eksternal dan matriks SWOT. Hasil identifikasi matriks faktor strategik internal (IFAS) dengan jumlah skor 2,85 dan matriks faktor strategik eksternal (EFAS) dengan jumlah skor 2,70, dapat menjadi indikasi bahwa usaha budidaya ikan lele di lahan kering dengan kolam terpal di Kabupaten Gunungkidul masih dapat ditingkatkan, dengan memperhatikan ancaman harga jual pada saat panen raya, terus meningkatnya harga pakan serta pesaing dari luar wilayah Kabupatren Gunungkidul. Menurut Kusumawardani, Gumili, dan Rostini (2012), persaingan pasar perlu menggunakan sumber daya secara efisien, artinya seluruh sumber-sumber daya yang tersedia sepenuhnya digunakan.

\section{Matriks IE}

Matriks IE (Gambar 1) menunjukkan strategi yang saat ini diterapkan pada usaha budidaya ikan lele di lahan kering di Kabupaten Gunungkidul. IE yang diperoleh dari penguraian dan pembobotan faktor-faktor strategik internal dan eksternal, budidaya lele di lahan kering di Kabupaten Gunungkidul berada pada posisi pertumbuhan dan stabilitas. Hal ini menunjukan bahwa usaha budidaya ikan lele di lahan kering dengan menggunakan kolam terpal di Kabupaten Gunungkidul melakukan strategi mempertahankan dan memelihara teknis pelaksanaan usaha yang saat ini sedang dilaksanakan oleh para pembudidaya merupakan strategi yang digunakan saat ini merupakan strategi terbaik. Hal tersebut sesuai dengan pendapat Iskandar et al (2013), pengembangan lahan untuk operasional dan segmentasi usaha sesuai dengan permintaan dan potensi pasar.

Dengan strategi ini, maka pertumbuhan dan pengembangan usaha dapat meningkatkan pendapatan pembudidaya ikan lele dengan memanfaatkan kekuatan dan peluang yang ada dengan melakukan pengaturan pola panen dan budidaya, serta efisiensi penggunaan pakan. Strategi ini perlu dilakukan dengan penuh kehatihatian tinggi terhadap adanya ancaman penyebaran penyakit dan pesaing dari luar wilayah Kabupaten Gunungkidul.

\section{Matrik SWOT}

Pemilihan strategi yang terbaik adalah kombinasi antara meminimalkan kelemahan dengan memanfaatkan peluang yang ada. Untuk memaksimalkan pendapatan pembudidaya ikan lele, gabungan antara strategi SO, Strategi WO dan strategi ST adalah merupakan strategi yang tepat untuk dipilih oleh pembudidaya untuk meningkatkan usahanya. 
Tabel 5. IFAS usaha budidaya ikan Lele di lahan kering di Kabupaten Gunungkidul Provinsi Daerah Istimewa Yogjakarta

\begin{tabular}{llcc}
\hline \multicolumn{1}{c}{ Faktor Strategik Internal } & Bobot & Rating & Bobot $\mathbf{x}$ Rating \\
\hline Kekuatan & & & \\
1. Sebagai tambahan penghasilan & 0,20 & 4 & 0,80 \\
2. Minat membudidayakan ikan lele tinggi & 0,05 & 3 & 0,15 \\
3. Meningkatkan gizi keluarga gizi keluarga & 0,10 & 3 & 0,30 \\
4. Menggunakan tenaga kerja keluarga & 0,10 & 4 & 0,40 \\
5. Menciptakan lapangan kerja & 0,10 & 3 & 0,30 \\
\hline Kelemahan & & & \\
1. Keterampilan pengelolaan yang kurang baik & 0,20 & 2 & 0,30 \\
2. Kepemilikan kolam dengan jumlah terbatas & 0,10 & 2 & 0,20 \\
3. Modal kerja masih minim & 0,05 & 2 & 0,10 \\
4. Masih sebagai usaha sampingan & 0,05 & 2 & 0,10 \\
5. Masih dalam tahap mengembangkan budidaya & 0,05 & 2 & 2,85 \\
$\quad$ ikan lele & & & \\
\hline
\end{tabular}

Tabel 6. EFAS usaha budidaya ikan Lele di lahan kering di Kabupaten Gunungkidul Provinsi Daerah Istimewa Yogjakarta

\begin{tabular}{llcc}
\hline \multicolumn{1}{c}{ Faktor Strategik Eksternal } & Bobot & Rating & Bobot x Rating \\
\hline $\begin{array}{l}\text { Peluang } \\
\text { 1. Keunggulan budidaya dengan kolam terpal }\end{array}$ & 0,20 & 4 & 0,80 \\
2. Daya tahan ikan lele terhadap lingkungan & 0,10 & 3 & 0,30 \\
3. Permintaan pasar cukup tinggi & 0,15 & 3 & 0,45 \\
4. Lahan kering masih tersedia untuk & 0,05 & 4 & 0,20 \\
$\quad$ pengembangan budidaya ikan lele & & 3 & 0,15 \\
5. Dapat dibudidayakan pada lahan terbatas & 0,05 & 2 & 0,10 \\
\hline Ancaman & & 2 & 0,30 \\
1. Benih sulit diperoleh saat musim tanam & 0,05 & 1 & 0,10 \\
2. Harga pakan terus meningkat & 0,15 & & \\
3. Persaingan dengan ikan lele dari luar & 0,10 & 2 & 0,10 \\
$\quad$ Kabupaten Gunungkidul & & 1 & 0,20 \\
4. Harga yang ditentukan tengkulak & 0,05 & 2,70 \\
5. Pengaruh musim yang tidak menentu & 0,10 & 1,00 & \\
\hline
\end{tabular}

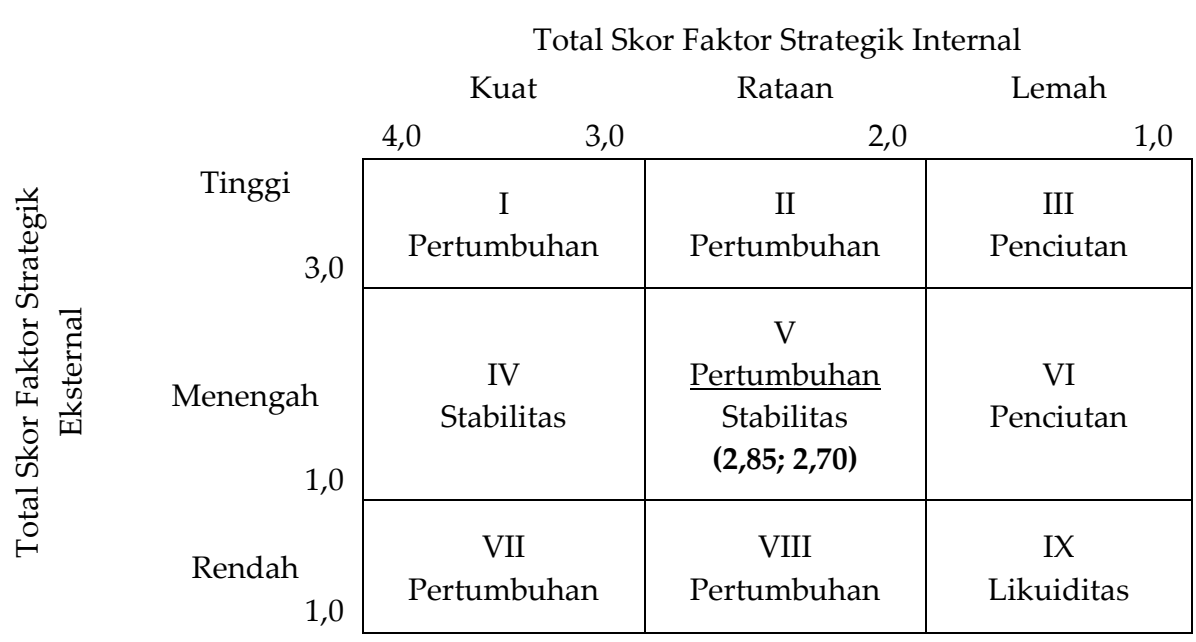

Gambar 1. Matriks Internal-Eksternal 
Memperluas target pasar melalui pengembangan produktivitas serta mutu ikan lele, dan pangsa pasar yang lebih tepat untuk meningkatkan efisiensi modal usaha. Menurut Suhendar et al (2010), dengan perkembangan dan perluasan pasar serta konsumen yang selama ini tidak terakomodasi akibat keterbatasan informasi dan jarak dapat dilayani. Strategi ini diyakini akan bermanfaat untuk meningkatkan penjualan atau pendapatan usaha. Pelaksanaan strategi tersebut membutuhkan dukungan promosi yang tepat. Strategi selanjutnya meningkatkan jumlah konsumen yang potensial untuk meningkatkan keuntungan bagi para pembudidaya ikan lele di lahan kering di Kabupaten Gunungkidul. Menurut Nainggolan et al (2010), keunggulan pemasaran adalah harus dapat meningkatkan pelayanan dalam penjualannya.

Strategi yang telah dirumuskan pada analisis SWOT (Gambar 2) perlu diimplementasikan pada pola usaha pembudidaya. Langkahlangkah tersebut dapat diimplementasikan pada aspek kemampuan manajerial pembudidaya ikan lele dengan meningkatkan keterampilan dan kemampuan pengelolaan budidaya ikan lele di lahan kering di Kabupaten Gunungkidul Provinsi DI Yogjakarta, sehingga dapat dijadikan salah satu usaha keluarga yang menguntungkan.

\begin{tabular}{|c|c|c|}
\hline Eksternal (EFAS) & $\begin{array}{l}\text { STRENGTH }(S) \\
\text { 1. Sebagai tambahan penghasilan } \\
\text { 2. Minat membudidayakan lele } \\
\text { tinggi } \\
\text { 3. Meningkatkan gizi keluarga } \\
\text { gizi keluarga } \\
\text { 4. Menggunakan tenaga kerja } \\
\text { keluarga } \\
\text { 5. Menciptakan lapangan kerja }\end{array}$ & $\begin{array}{l}\text { WEAKNESSES }(W) \\
\text { 1. Keterampilan pengelolaan } \\
\text { kurang baik } \\
\text { 2. Kepemilikan kolam dengan } \\
\text { jumlah terbatas } \\
\text { 3. Modal kerja masih minim } \\
\text { 4. Masih sebagai usaha } \\
\text { sampingan } \\
\text { 5. Masih dalam tahap } \\
\text { mengembangkan budidaya } \\
\text { ikan lele }\end{array}$ \\
\hline $\begin{array}{l}\text { OPPORTUNITIES }(O) \\
\text { 1. Keunggulan budidaya } \\
\text { dengan kolam terpal } \\
\text { 2. Daya tahan ikan lele terhadap } \\
\text { lingkungan } \\
\text { 3. Permintaan pasar cukup } \\
\text { tinggi } \\
\text { 4. Lahan kering masih tersedia } \\
\text { untuk pengembangan } \\
\text { budidaya ikan lele } \\
\text { 5. Dapat dibudidayakan pada } \\
\text { lahan terbatas }\end{array}$ & $\begin{array}{l}\text { Strategi SO } \\
\text { a. Perluasan dan pengembangan } \\
\text { usaha budidaya dengan kolam } \\
\text { terpal } \\
\text { b. Meningkatkan produktivitas } \\
\text { c. Meningkatkan mutu produk ikan } \\
\text { lele } \\
\text { d. Diversifikasi produk ikan lele }\end{array}$ & $\begin{array}{l}\text { Strategi WO } \\
\text { a. Menerapkan pola manajemen } \\
\text { b. Pemeliharaan yang baik } \\
\text { c. Perluasan pemilikan kolam } \\
\text { terpal } \\
\text { d. Menjalin kerjasama dengan } \\
\text { pihak lembaga keuangan } \\
\text { e. Meningkatkan keterampilan } \\
\text { budidaya }\end{array}$ \\
\hline $\begin{aligned} \text { THREATS }(T) \\
\text { 1. } \\
\text { Benih sulit diperoleh saat } \\
\text { musim tanam } \\
\text { 2. } \begin{array}{l}\text { Harga pakan terus } \\
\text { meningkat }\end{array} \\
\text { 3. Persaingan dengan ikan lele } \\
\text { dari luar Kabupaten } \\
\text { Gunung Kidul } \\
\text { 4. Harga ditentukan tengkulak } \\
\text { 5. Pengaruh musim tidak } \\
\text { menentu }\end{aligned}$ & $\begin{array}{l}\text { Strategi ST } \\
\text { a. Melakukan pendederan benih lele } \\
\text { sendiri } \\
\text { b. Memperluas pangsa pasar } \\
\text { potensial. } \\
\text { c. Bergabung dan berkelompok } \\
\text { d. Melakukan pengaturan pola tebar } \\
\text { benih ikan lele atau pola } \\
\text { budidaya. }\end{array}$ & $\begin{array}{l}\text { Strategi WT } \\
\text { a. Memaksimalkan penggunaan } \\
\text { sarana produksi untuk } \\
\text { mengantisipasi kenaikan biaya } \\
\text { produksi }\end{array}$ \\
\hline
\end{tabular}

Gambar 2. Matriks SWOT usaha budidaya ikan lele di lahan kering di Kabupaten Gunungkidul Provinsi DIY 


\section{KESIMPULAN}

Usaha budidaya ikan lele dengan menggunakan teknologi kolam terpal di lahan kering di Kabupaten Gunungkidul mempunyai prospek cukup cerah dan layak dikembangkan.

Berdasarkan analisa keuangan, harga jual ikan lele konsumsi rataan per kilogram ditingkat pembudidaya pada luas kolam $12-16 \mathrm{~m}^{2}$ adalah Rp10.394,74, luas kolam 20-25 $\mathrm{m}^{2}$ adalah Rp10.673,08 dan luas kolam 20-45 $\mathrm{m}^{2}$, adalah Rp10.291,67, produksi yang dihasilkan pada luas kolam 12-16 $\mathrm{m}^{2}$ adalah 3.642,95 ekor ikan lele konsumsi (setara 453,88 kg ikan lele), luas kolam 20-25 $\mathrm{m}^{2}$ adalah 7.180 ekor ikan lele konsumsi (setara $868 \mathrm{~kg}$ ikan lele) dan pada luas kolam 30$45 \mathrm{~m}^{2}$ adalah 10.661,01 ekor ikan lele konsumsi (setara 1.242,06 kg ikan lele), perolehan pendapatan per siklus budidaya Rp4.673.620,95 atau Rp1.557.874 dalam satu tahun periode budidaya (luas kolam 12-16 $\mathrm{m}^{2}$ ), Rp9.195.341 atau Rp3.065.114 dalam satu tahun periode budidaya (luas kolam 20-25 m²) dan Rp12.806.333,79 atau Rp4.268.777,93 dalam satu tahun periode budidaya (luas kolam 30-45 $\mathrm{m}^{2}$ ), keuntungan yang diperoleh $\mathrm{Rp} 832.668,59$ atau rataan senilai Rp277.556,20 per siklus budidaya (luas kolam 12$\left.16 \mathrm{~m}^{2}\right), \quad \mathrm{Rp} 2.248 .907,48$. atau rataan senilai Rp749.635,83 per siklus budidaya (luas kolam 20$25 \mathrm{~m}^{2}$ ) dan Rp3.245.323,85 atau rataan senilai Rp1.081.774,62 per siklus budidaya untuk luas kolam 30-45 m²; BEP volume produksi 344,54 kg pada harga Rp7.890,78/kg untuk luas kolam 12-16 $\mathrm{m}^{2}, 571,13 \mathrm{~kg}$ pada harga Rp7.020,22, luas kolam $12-16 \mathrm{~m}^{2} 807,99 \mathrm{~kg}$ pada harga Rp6.695,01 untuk luas kolam 30-45 m²; Nilai Gross B/C Ratio 1,22 (luas kolam 12-16 m²), 1,32 (luas kolam 20-25 m²) dan 1,34 (luas kolam 30-45 $\mathrm{m}^{2}$ ), serta berdasarkan kriteria jangka waktu pengembalian modal (PBP) diperoleh hasil 3,81 tahun (luas kolam 12-16 m²), 1,32 (luas kolam 20-25 m²) dan 1,34 (luas kolam 30$\left.45 \mathrm{~m}^{2}\right)$.

Untuk memaksimalkan pendapatan pembudidaya ikan lele, maka dilakukan penambahan jumlah dan luas kolam dan mengembangkan usaha budidaya, menerapkan cara-cara pemeliharaan dan budidaya yang baik, serta memperluas jangkauan pasar mulai dari konsumen perorangan, pasar tradisional rumah makan dan restoran hingga ke pasar modern.

\section{DAFTAR PUSTAKA}

Iskandar, A.A., S. Raharja dan K. Sumantadinata. 2013. Pengembangan Agribisnis Ikan Balita di UD Suhada, Kabupaten Cianjur. Jurnal Manajemen IKM, 8 (2): 181-189.

BPS (Badan Pusat Statistik). 2008. Gunungkidul Dalam Angka 2008. Badan Pusat Statistik Kabupaten Gunungkidul, Gunungkidul.

Gunawan, S. 2009. Kiat Sukses Budidaya Lele di Lahan Sempit. Agro Media, Jakarta.

Jaja, A. Suryani dan K. Sumantadinata. 2013. Usaha Pembesaran dan Pemasaran Ikan Lele serta Strategi Pengembangannya di UD Sumber Rezeki Parung, Jawa Barat. Jurnal Manajemen IKM, 8 (1): 45-56.

Kantor Deputi Menegristek Bidang Pendayagunaan dan Pemasyarakatan Ilmu Pengetahuan dan Teknologi, 2000. Budidaya Ikan Lele (Clarias), Jakarta.

Kusumawardani, IS., I. Gumila dan I. Rostini. 2012. Analisis Surplus Konsumen dan Surplus Produsen Ikan Segar di Kota Bandung. Jurnal Perikanan dan Kelautan, 3 (4): 141-150.

Mahyuddin, K. 2010. Panduan Lengkap Agribisnis Lele. Penebar Swadaya, Jakarta.

Nainggolan, T.Y., K. Sumantadinata dan A. Suryani. 2010. Strategi Pengembangan Usaha "Nila Puff" dalam Meningkatkan Pendapatan IKM Pengolahan Hasil Perikanan pada CV." X" di Cibinong, Bogor. Manajemen IKM, 5 (2): 132-144.

Pearce. J.A.II and R.B. Robinson Jr, 1998. Strategic Management, Third Edition, Richard D. Irwin, Illions.

Septiara, I., I. Maulina dan I.D. Buwono. 2012. Analisis Pemasaran Ikan Mas Koki (Carassius Auratus) di Kelompok Pembudidaya Ikan Kelapa Ciung Kecamatan Cimalaka Kabupaten Sumedang. Jurnal Perikanan dan Kelautan, 3 (3): 69-73.

Suhendar, U., Soewarno T.S dan N.S. Palupi. 2010. Kajian Strategi Pemasaran Ikan Asap (Smoked Fish) di UKM Petikan Cita Halus Citayam, Bogor. Manajemen IKM, 5 (2): 145156.

Sukardono, E., M. Sarma dan K. Sumantadi-nata. 2013. Strategi Pemasaran Restoran Pecel Lele Lela Cabang Pinangranti, Jakarta Timur. Manajemen IKM, 8 (2): 170-180. 